\title{
Antidiabetic, cytotoxic and antioxidant activities of oil extracted from Acrocomia aculeata pulp
}

\author{
Perla V. B. da Silva, Marianne M. Ramiro, Edna K. K. Iriguchi, William A. \\ Corrêa, Jennifer Lowe, Claudia A. L. Cardoso, Arielle C. Arena, Cândida A. L. \\ Kassuya \& Rozanna M. Muzzi
}

To cite this article: Perla V. B. da Silva, Marianne M. Ramiro, Edna K. K. Iriguchi, William A. Corrêa, Jennifer Lowe, Claudia A. L. Cardoso, Arielle C. Arena, Cândida A. L. Kassuya \& Rozanna M. Muzzi (2019) Antidiabetic, cytotoxic and antioxidant activities of oil extracted from Acrocomia aculeata pulp, Natural Product Research, 33:16, 2413-2416, DOI: 10.1080/14786419.2018.1446006

To link to this article: https://doi.org/10.1080/14786419.2018.1446006

View supplementary material ¿ Published online: 28 Feb 2018.

Submit your article to this journal $₫$

III Article views: 145

Q View related articles $\sqsubset$

View Crossmark data $\widetilde{ }$

Citing articles: 4 View citing articles ¿ð 


\title{
Antidiabetic, cytotoxic and antioxidant activities of oil extracted from Acrocomia aculeata pulp
}

\author{
Perla V. B. da Silva ${ }^{a}$, Marianne M. Ramiro ${ }^{a}$, Edna K. K. Iriguchi ${ }^{a}$, William A. Corrêa ${ }^{a}$, \\ Jennifer Lowe ${ }^{b}$, Claudia A. L. Cardosoc, Arielle C. Arenad ${ }^{d}$, Cândida A. L. Kassuya ${ }^{a}$ and \\ Rozanna M. Muzzia
}

aFederal University of Grande Dourados, Dourados, Brazil; bFederal University of Rio de Janeiro, Rio de Janeiro, Brazil; 'Mato Grosso do Sul State University, Dourados, Brazil; ${ }^{d}$ Institute of Biosciences of Botucatu, São Paulo State University (UNESP), São Paulo, Brazil

\section{ABSTRACT}

This study evaluated the hypoglycemic effect of the oil extracted from the Acrocomia aculeata pulp (OPAC) in normoglycemic rats and streptozotocin (STZ), fructose-induced diabetic rat models and its in vitro antioxidant and cytotoxic potential. OPAC $(3,30$ or $300 \mathrm{mg} / \mathrm{kg}$, v.o.) significantly decreased $(p<0.05)$ the high glucose levels induced by a high fructose-diet in rats. Persistent treatment with OPAC for 24 days also reduced the high plasmatic glucose induced by STZ. In normoglycemic animals, OPAC significantly decreased glucose levels. While $A$. aculeata oil exhibited good in vitro antioxidant activity, no sign of cytotoxicity was observed in LLC-PK1 cells $(5-500 \mu \mathrm{g} / \mathrm{mL})$. OPAC has antidiabetic and antioxidant activities without causing in vitro cytotoxicity.

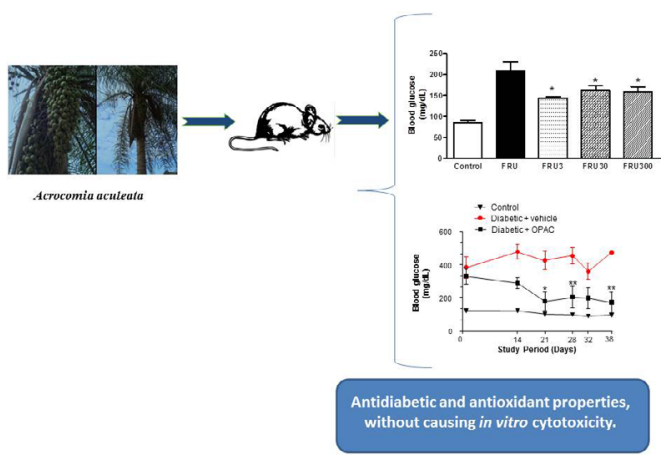

\section{ARTICLE HISTORY}

Received 2 May 2017

Accepted 23 February 2018

\section{KEYWORDS}

Medicinal plants; hypoglycemic activity; antioxidant activity 


\section{Introduction}

Fruits of Acrocomia aculeata (Jacq.) Lodd (Palmaceae), popularly known as 'macauba', are used for nutritional purposes and for the treatment of some disorders, such inflammation, diabetes, among others (Sosnowska and Balslev 2009). This species, rich in fatty acids and carotenoids (Hiane et al. 2005; Coimbra and Jorge 2012), has been used for a long time by indigenous people for treatment of diabetes (Sosnowska and Balslev 2009). However, there is not enough evidence to support its hypoglycemic activity. Thus, we evaluated the hypoglycemic effect of the oil extracted from A. aculeata (OPAC) pulp in experimental models of fructose-induced diet and streptozotocin (STZ)-induced diabetes rats and its in vitro antioxidant and cytotoxic potential.

\section{Results and discussion}

Hypoglycemic compounds from methanol extract of the A. mexicana root (Syn. of A. aculeata) were isolated and showed a significant blood glucose lowering effect on normal and alloxan-diabetic mice (Perez et al. 1997). In this study, despite having different mechanisms, both models also revealed the hypoglycemic activity of the oil obtained from A. aculeata pulp. A diet rich in fructose can cause several metabolic changes such as hyperglycemia, reduced response to insulin (insulin resistance), and metabolic dyslipidemia (Basciano and Federico 2005). Whereas the animals which received only the fructose-rich diet exhibited hyperglycemia, the animals which received OPAC for 5 days had a reduction $(p<0.05)$ in blood glucose levels at all doses tested (Figure S1). Since the hypoglycemic effect was more effective at the lowest dose ( $3 \mathrm{mg} / \mathrm{kg}$ ), we decided using this dose in the streptozotocin-induced diabetes assay.

In STZ-induced diabetes, hyperglycemia and $\beta$-cell damage have been implicated in the etiology and pathology of diabetes (Luo et al. 1998). Although STZ high-dose causes damage in insulin secretion mimicking type 1 diabetes, STZ low-dose has been known for inducing a mild impairment of insulin secretion which is similar to the feature of the later stage of type 2 diabetes (Reed et al. 2000). The mechanism of action of STZ in $\beta$-cell of the pancreas seems to be mediated by oxidative damage, via inhibition of free radical scavenger-enzymes and thereby enhancing the production of reactive oxygen species and nitric oxide. The cytotoxic effects of STZ on the pancreatic islets can be prevented by compounds with antioxidant activities (Jia et al. 2000). The administration of OPAC ( $3 \mathrm{mg} / \mathrm{kg}$ ) resulted in a rapid decrease of blood glucose levels within 21 days from the beginning of the treatment compared with untreated diabetic rats. The continual treatment of diabetic rats with OPAC caused a slight increase in the blood glucose level (day 28), however, after day 32 the blood glucose level decreased to the control level again (Figure S2).

In addition, OPAC markedly reduced water consumption of diabetic animals, suggesting a normalization of polydipsia in Type 1 diabetes (Table S2). Since the diabetes can deplete the activity of antioxidative defense system (Kamalakkannan and Prince 2006), the treatment with OPAC, rich in oleic acid and $\beta$-carotene (Traesel et al. 2014), could prevent the increase of glucose levels via reduction of the oxidative stress and lipid peroxidation, preserving the function of the pancreas. The results of the oral glucose tolerance test in normoglycemic rats demonstrated that OPAC $(3 \mathrm{mg} / \mathrm{kg})$ reduced $(p<0.05)$ the blood glucose levels of the nondiabetic animals (leading to hypoglycemia), suggesting the ability of this oil to improve 
glucose tolerance in normal rats. The hypoglycemic effect which was detected may be similar to the one of metformin (positive control) (Figure S3) and it may be possibly due to a mechanism which is independent from insulin or the increased utilization of glucose by peripheral tissues.

Studies indicated that A. aculeata oil does not have either toxic or cytotoxic, genotoxic, or mutagenic effects in rats (Traesel et al. 2014). Corroborating with these results, the cytotoxicity assay of OPAC has not showed any decrease in renal epithelial cell viability with doses up to $500 \mu \mathrm{g} / \mathrm{mL}$ after 3, 6 or $18 \mathrm{~h}$ incubation when compared with the control. It was demonstrated by the similar number of death cells stained with propidium iodide among the groups (Figure S4). Due to the low solubility of this oil, it was not possible to increase the concentration in order to obtain an $\mathrm{IC}_{50}$ value. These data demonstrate that OPAC could be safely tested on diabetes models since it showed no toxicity in rats (confirmed in previous studies) or renal epithelial cells. Since plants with antioxidant properties are excellent candidates for antidiabetic drugs, we evaluated the in vitro antioxidant potential of A. aculeata. The oil showed better results for the $\beta$-carotene/linoleic acid than by DPPH • method, resulting in an $\mathrm{IC}_{50}$ with lower concentrations in this test. The $\beta$-carotene/linoleic acid assay allows evaluating the ability of the compound to prevent the $\beta$-carotene oxidation, providing protection from free radicals generated during linoleic acid peroxidation (Tepe et al. 2005).

In this assay, the sample showed a higher IC $\mathrm{C}_{50}$ value compared to quercetin, but the $\mathrm{IC}_{50}$ value against tannic acid was lower (Table S3). Phenolic compounds, such as quercetin and tannic acid, are able to decrease glucose levels by reducing oxidative stress (Kamalakkannan and Prince 2006). Thus, we found that the oil exhibited good antioxidant activity, even greater than the one offered by standard tannic acid. The best results obtained from the $\beta$-carotene/ linoleic acid assay may have occurred because of the lipid characteristics of the sample. This antioxidant activity may have contributed to the hypoglycemic effect of this oil and could be attributed to the compounds present in this oil.

\section{Conclusion}

The A. aculeata oil has potential antidiabetic and antioxidant properties to treat diabetes, without causing in vitro cytotoxicity. Therefore, this study suggests that consuming the pulp of $A$. aculeata palm oil can be useful as a functional food for diabetic patients.

\section{Disclosure statement}

No potential conflict of interest was reported by the authors.

\section{Funding}

This study was supported by the CAPES and the FAPESP [grant number 2013/01802-3].

\section{References}

Basciano H, Federico L. 2005. Fructose, insulin resistance, and metabolic dyslipidemia. Nutr Metab (Lond). 2(1):5. 
Coimbra MC, Jorge N. 2012. Fatty acids and bioactive compounds of the pulps and kernels of Brazilian palm species, guariroba (Syagrus oleraces), jerivá (Syagrus romanzoffiana) and macaúba (Acrocomia aculeata). J Sci Food Agric. 92:679-684.

Hiane PA, Ramos MM, Ramos MIL, Macedo MLR. 2005. Óleo da polpa e amêndoa de bocaiúva, Acrocomia aculeata (Jacq.) Lodd. caracterização e composição em ácidos graxos. Brazilian J Food Technol. 8:256-259.

Jia YJ, Xin ZL, Hu HT, Ren HM, Wang WX. 2000. Melatonin protects $\beta$-cell from streptozotocin induced injury. J Xi'an Med Univ. 21:13-15.

Kamalakkannan N, Prince PS. 2006. Antihyperglycaemic and antioxidant effect of rutin, a polyphenolic flavonoid, in streptozotocin-induced diabetic wistar rats. Basic Clin Pharmacol Toxicol. 98(1):97-103.

Luo J, Quan J, Tsai J, Hobensack CK, Sullivan C, Hector R, Reaven GM. 1998. Nongenetic mouse models of non-insulin-dependent diabetes mellitus. Metabolism. 47:663-668.

Perez S, Perez RM, Zavala MA, Vargas R. 1997. Coyolosa, a new hypoglicemic from Acrocomia mexicana. Pharm Acta Helv. 72:105-111.

Reed MJ, Meszaros K, Entes LJ, Claypool MD, Pinkett JG, Gadbois TM, Reaven GM. 2000. A new rat model of type 2 diabetes: the fat-fed, streptozotocin-treated rat. Metabolism. 49:1390-1394.

Sosnowska J, Balslev H. 2009. American palm ethnomedicine: a meta-analysis. J Ethnobiol Ethnomed. 5:43.

Tepe B, Daferera D, Sokmen A, Sokmen B, Polissiou M. 2005. Antimicrobial and antioxidant activity of the essential oil and various extracts of Cyclotrichium origanifolium (Labill.) Manden \& Scheng. J Food Eng. 69:335-342.

Traesel GK, de Souza JC, de Barros AL, Souza MA, Schmitz WO, Muzzi RM, Oesterreich SA, Arena AC. 2014. Acute and subacute ( 28 days) oral toxicity assessment of the oil extracted from Acrocomia aculeata pulp in rats. Food Chem Toxicol. 74:320-325. 